\title{
Composition and origin of amber ice and its influence on the behaviour of cold glaciers in the McMurdo Dry Valleys, Antarctica
}

\author{
Sarah MAGER, ${ }^{1}$ Sean FITZSIMONS, ${ }^{1}$ Russell FREW, ${ }^{2}$ Denis SAMYN, ${ }^{3}$ \\ Reginald LORRAIN ${ }^{3}$ \\ ${ }^{1}$ Department of Geography, University of Otago, PO Box 56, Dunedin, New Zealand \\ E-mail: smm@geography.otago.ac.nz \\ ${ }^{2}$ Department of Chemistry, University of Otago, PO Box 56, Dunedin, New Zealand \\ ${ }^{3}$ Laboratoire de Glaciologie, Université Libre de Bruxelles, CP 160/03, Avenue F.D. Roosevelt 50, B-1050 Brussels, Belgium
}

\begin{abstract}
This paper examines the basal ice sequence of Rhone Glacier, a cold-based glacier in the McMurdo Dry Valleys, Antarctica, using isotopic and solute chemistry data. Three different ice facies are identified: englacial, amber and stratified. The englacial facies is clean, bubbly ice of meteoric origin and is underlain by an amber facies. Amber ice is a characteristic of cold alpine glaciers in the McMurdo Dry Valleys and is distinctive for its high solute concentrations and much higher strain rates compared with the overlying englacial ice and the underlying stratified ice. Analysis of the stratified facies reveals an isotopic signature indicative of melt then refreeze processes and it is most likely associated with apron entrainment at the margin. By contrast, the amber facies has a co-isotopic slope of 8 and plots on a meteoric waterline. The inclusion of impurities in the amber ice reveals prolonged contact with the bed, and its depleted isotopic signature is consistent with ice formed during a cooler period. Comparison of the basal sequence of Rhone Glacier with other cold-based glaciers in the McMurdo Dry Valleys reveals strong similarities between valley-side glaciers (e.g. Meserve and Rhone Glaciers), whereas valley-floor glacier basal sequences (e.g. Suess Glacier) are characterized by structurally complex amalgamations of ice and debris.
\end{abstract}

\section{INTRODUCTION}

Amber ice was first described by Holdsworth (1974) in the basal zone of Meserve Glacier, Wright Valley, Antarctica (Fig. 1). The principal characteristics of amber ice are its distinctive yellow hue, massive appearance, suspended finegrained sediment, high solute concentration and bubbly ice matrix (Anderton, 1974; Holdsworth, 1974; Cuffey and others, 2000a,b). In Meserve Glacier the solute concentrations of the amber ice were seven times greater than that of the adjacent meteoric-origin ice. Calcium concentration was particularly high and reached ten times the values found in englacial ice $\left(5.9 \mathrm{mg} \mathrm{L}^{-1}\right.$ vs $0.6 \mathrm{mg} \mathrm{L}^{-1}$ ) (Holdsworth, 1974). Examination of the particles dispersed in the amber ice showed that the particle diameters, $d$, ranged from $0.2 \mathrm{~mm}(2.3 \phi)$ to $0.7 \mathrm{~mm}(0.5 \phi) \quad\left(\phi=-\log ^{2} d\right)$ which is equivalent to a fine to very fine sand on the UddenWentworth scale (Holdsworth, 1974).

Although the presence of fine-grained sediment makes measurement of the crystal fabric difficult, Anderton (1974) observed a strong preferred crystal orientation normal to the glacier bed (glide planes parallel to the bed). In addition, most of the air bubbles in the amber ice were strongly aligned parallel to flow and typically smaller than $1 \mathrm{~mm}$, which is not as large as that of air bubbles in the overlying englacial ice. Cuffey and others $(2000 a, b)$ re-excavated the Meserve Glacier basal sequence and found that the amber ice had 100 times the debris content of the overlying and underlying ice layers. In isotopic composition, the amber ice was $40 \%$ lighter in $\delta \mathrm{D}$ than the underlying ice, but identical to the overlying englacial ice (Cuffey and others, 2000b). Further comparison of the $\mathrm{Ar} / \mathrm{N}_{2}$ ratio and $\mathrm{CO}_{2}$ concentration of gas bubbles showed that the amber ice was indistinguishable from englacial ice. Isotopic and gas composition analyses led Cuffey and others (2000b) to suggest that the amber ice had formed without bulk melt and refreezing. Such an interpretation is consistent with the original interpretation by Holdsworth (1974), who suggested that amber ice formed by solid-state diffusion of solutes and fine particles from prolonged contact with the bed. They concluded that diffusion was facilitated by the presence of thin layers of water at the interfaces between debris particles and ice (Cuffey and others, 2000b).

Although most of our knowledge of amber ice comes from studies of Meserve Glacier, it has been observed in other glaciers in the McMurdo Dry Valleys including Victoria Lower and Suess Glaciers (Fig. 1) (Chinn, 1991; Humphreys and Fitzsimons, 1996; Fitzsimons and others, 1999, 2001). In both these glaciers the amber-ice solute concentrations are lower than values observed in Meserve Glacier. In Meserve and Victoria Lower Glaciers the dominant cation is sodium ( 8.2 and $3.7 \mathrm{mg} \mathrm{L}^{-1}$ respectively), whereas in Suess Glacier the concentration of sodium is low $\left(0.9 \mathrm{mg} \mathrm{L}^{-1}\right)$ and the dominant cation is calcium $\left(3.6 \mathrm{mg} \mathrm{L}^{-1}\right)$. These differences may relate to relative distance from the ocean, the nature of the glacier substrate, the geochemistry of the substrate or a combination of these variables.

Although amber ice is visually distinct from englacial ice, they are indistinguishable on the basis of gas and isotopic compositions (Cuffey and others, 2000b; Sleewaegen and others, 2003). The common interpretation is that amber ice has not undergone melt then refreeze, but this does account for the presence of relatively high solute and suspendeddebris concentrations in the ice. Isotopic analyses of amber ice from Suess Glacier ranged from $\delta^{18} \mathrm{O}-32.6$ to $-33.5 \%$ 


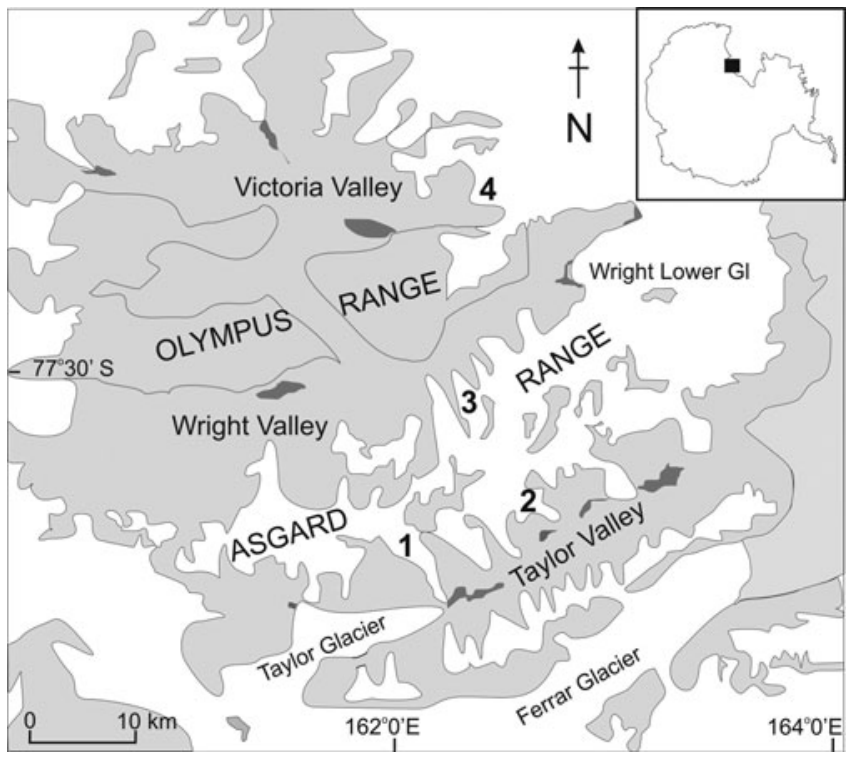

Fig. 1. Map of the McMurdo Dry Valleys showing the location of glaciers mentioned in the text; ice-covered areas are shown in white. 1. Rhone Glacier; 2. Suess Glacier; 3. Meserve Glacier; 4. Victoria Lower Glacier.

and $\delta \mathrm{D}-260$ to $-264 \%$, which overlaps the values for englacial ice samples (Sleewaegen and others, 2003). The amber ice plotted on a meteoric waterline, and could not be isotopically distinguished from englacial ice (Sleewaegen and others, 2003). The peak shear strength of the amber ice in Suess Glacier averaged 0.9 MPa, which is considerably lower than that of the englacial ice (1.4 MPa) or other basal ice units (1.3 MPa) (Fitzsimons and others, 1999). Amber ice is clearly weaker than the other basal ice units and englacial ice, leading Fitzsimons and others (2001) to conclude that strain was preferentially accommodated in the amber-ice layer although the degree to which amber ice influences glacier behaviour remains poorly understood.

Measurements of the relatively low strength of amber ice are consistent with the ice crystallography investigations on Suess Glacier (Samyn and others, 2005), because amber ice has equant, sub-millimetric sized crystals (average $0.7 \mathrm{~mm}$ ) with a strong lattice-preferred orientation. The driver of the small grain size is unclear, but grain growth appears to be constrained by sediment concentrations of only a few per cent by volume (Cuffey and others, 2000a). Small ice crystals are strongly associated with basal glide and are likely to influence the high plasticity of amber ice (Cuffey and others, 2000a). Thus grain-boundary processes like diffusion or sliding may occur at sub-zero temperatures (Cuffey and others, 2000b).

The aim of this study is to examine the composition, structure and deformation of amber ice to understand the origin of this unusual ice facies and to gain some insight into the influence of the ice on glacier behaviour. This study is focused on Rhone Glacier, which is a small alpine glacier in the Taylor Valley adjacent to the terminus of Taylor Glacier (Fig. 1). Although similar to Meserve Glacier, Rhone Glacier rests on a substrate of unconsolidated sediment, and the basal ice is thicker and structurally more complex. Data from this study explore the isotopic and chemical composition of Rhone Glacier's basal ice and its relation to glacier behaviour.

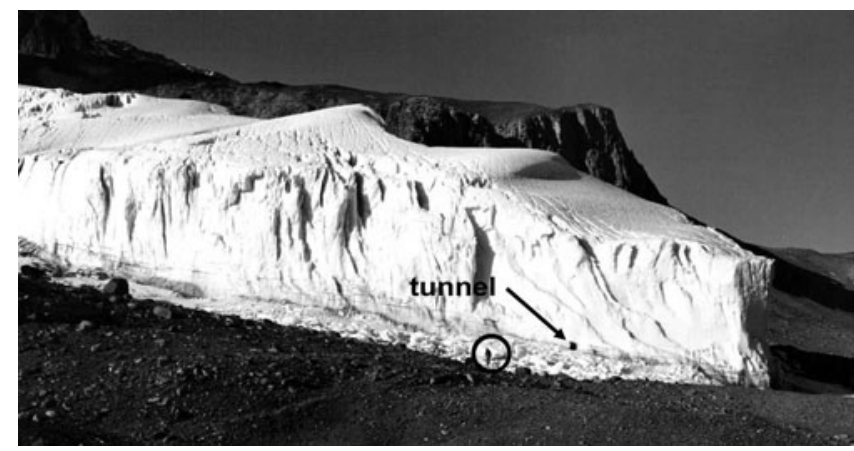

Fig. 2. True right terminus of Rhone Glacier showing location of tunnel excavated into the basal zone. A $1.8 \mathrm{~m}$ tall person is circled for scale.

\section{FIELD AREA AND METHODS}

Rhone Glacier flows down the southern face of the Asgard Range flanking the Taylor Valley, southern Victoria Land, Antarctica. The glacier descends from $2000 \mathrm{~m}$ and terminates approximately $200 \mathrm{~m}$ above the valley floor on a platform of till and deltaic sediments (Wilch and others, 1993). Like most glaciers in this part of Antarctica, it has high terminal cliffs $(18 \mathrm{~m})$ and a small ice-and-debris apron. Mean annual temperature for this area averages $-17.9^{\circ} \mathrm{C}$ (Doran and others, 2002), allowing glacier ice to remain sub-zero year-round.

A $10 \mathrm{~m}$ long tunnel was excavated on the western side of the glacier, approximately $100 \mathrm{~m}$ upstream of the terminus (Fig. 2). At the end of the tunnel, a $3 \mathrm{~m}$ shaft was excavated to the bed of the glacier, revealing a $3.5 \mathrm{~m}$ sequence of basal ice (Fig. 3a). Above the glacier bed is a $2 \mathrm{~m}$ layer of stratified ice characterized by broadly planar, alternating layers of clean bubbly ice and debris-bearing ice with variable bubble content. The stratified facies are overlain by $1.5 \mathrm{~m}$ of amber ice. Blocks of ice in a continuous sequence were extracted from the back wall of the shaft from the glacier bed to a height of $2.6 \mathrm{~m}$, and an additional block of englacial ice was extracted from the tunnel roof near the boundary between the amber and englacial facies.

Strain and displacement measurements were made using plumb lines and strain arrays. Each strain array consisted of a rectangle of stainless-steel bolts with cones milled from their heads. Distances between bolts were measured with a digital calliper with a precision of $0.01 \mathrm{~mm}$. The calliper was positioned on the bolts with conical pins attached on the calliper jaws, which fitted tightly into the cones. The arrays were resurveyed episodically for a year. During this time there was some bulging of the tunnel walls, which could have introduced errors relating to differences in closure rates with increasing overburden through the length of the tunnel. The systematic measurement error associated with the use of the calliper is $\pm 0.05 \mathrm{~mm}$, and equates to a shear strain-rate error of $0.0003 \mathrm{a}^{-1}$. Strain rates were calculated from the corners of triangles defined from the strain arrays using a numerical calculation of a Mohr circle based on the method outlined by Ramsay (1967) (Hambrey and Müller, 1978; Hambrey and others, 1980). We followed the convention of principal strain rates used by Sharp and others (1988) where $\dot{\varepsilon}_{1} \geq \dot{\varepsilon}_{3}$, extension is positive and $\varepsilon_{3}$ is always vertical. Shear strain rate was calculated as:

$$
\dot{\gamma}=\frac{\dot{\varepsilon}_{1}-\dot{\varepsilon}_{2}}{2}
$$




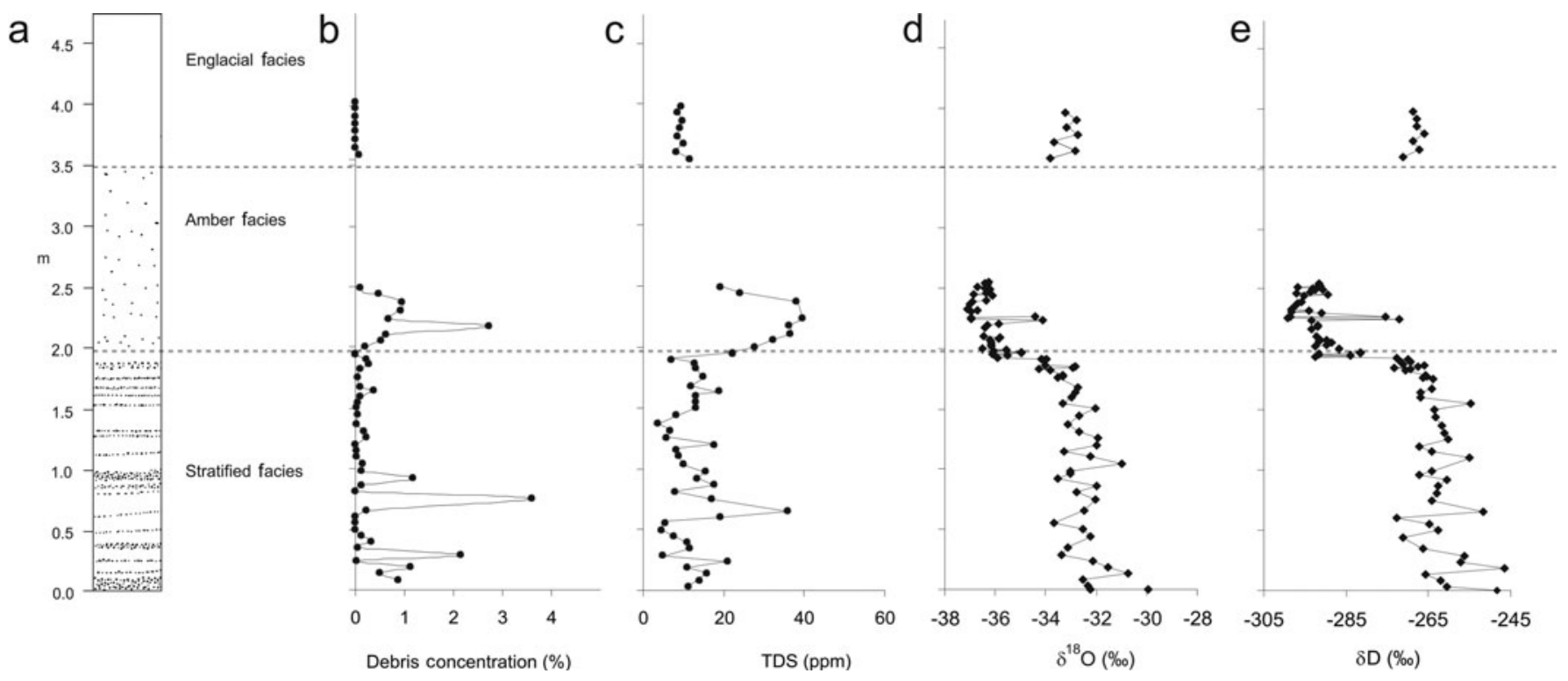

Fig. 3. Isotopic composition of the basal zone of Rhone Glacier showing (a) composite stratigraphic sequence of basal ice facies from two exposures in tunnel; (b) debris concentration; (c) total dissolved solids; (d) $\delta^{18} \mathrm{O}$ composition; and (e) $\delta \mathrm{D}$ composition.

If no wall bulging occurred, $\dot{\varepsilon}_{3}$ would be zero, which is not the case (Table 1). However, $\dot{\varepsilon}_{3}$ is almost an order of magnitude less than $\dot{\varepsilon}_{1}$. Consequently, we conclude that tunnel closure has not introduced major errors in the calculation of strain rates.

Ice samples were taken with an electric chainsaw fitted with tungsten carbide cutters. Individual blocks $200 \mathrm{~mm}$ wide by $300 \mathrm{~mm}$ high were cut in a vertical sequence, then placed in polythene bags and stored in insulated boxes for transport back to New Zealand where the ice was held at $-18^{\circ} \mathrm{C}$. Samples for analysis were taken with a bandsaw. Forty-six samples for isotopic analysis were cut at $50 \mathrm{~mm}$ intervals in the stratified and englacial ice, and 30 were cut at $10 \mathrm{~mm}$ intervals in the amber ice. Samples for solute analysis were taken at $50 \mathrm{~mm}$ intervals throughout the sequence. In the laboratory, measurements were made of the stable isotopes $\delta^{18} \mathrm{O}$ and $\delta \mathrm{D}$, and the solutes $\mathrm{Na}^{+}, \mathrm{Mg}^{2+}, \mathrm{K}^{+}$, $\mathrm{Ca}^{2+}, \mathrm{NH}_{4}{ }^{+}, \mathrm{Cl}^{-}, \mathrm{F}^{-}, \mathrm{NO}_{3}{ }^{-}, \mathrm{PO}_{4}{ }^{3-}$ and $\mathrm{SO}_{4}{ }^{2-}$. A VG Sira isotope ratio mass spectrometer (IRMS) with chemical reduction of hydrogen by chromium powder was used to measure hydrogen isotope ratios (Donnelly and others, 2001). The oxygen isotopes were measured by the reduction of liquid water to carbon dioxide by nickelized carbon using a EuroVector EA mass spectrometer (Farquhar and others, 1997). Results are expressed in $\delta$ notation normalized to Standard Mean Ocean Water (SMOW). Precision is $\pm 0.5 \%$ for $\delta \mathrm{D}$ and $\pm 0.1 \%$ for $\delta^{18} \mathrm{O}$.

The chloride, fluoride and sulphate ions were measured with ion chromatography on a Jasco PU-980 high-performance liquid chromatography (HPLC) pump and a Shimadzu Chromatopac C-R3A. Prior to analysis, all samples were filtered to remove particles larger than $0.2 \mu \mathrm{m}$. Nitrate, phosphate and ammonia were measured using a Foss FIAStar 5000 flow injection analyser (FIA). The detection limit is $0.1 \mathrm{mg} \mathrm{L}^{-1}$ for all ionic species, except for fluoride, which has a detection limit of $0.5 \mathrm{mg} \mathrm{L}^{-1}$.

Cations were measured using atomic absorption spectrometry (AAS). Prior to analysis, sample aliquots of $10 \mathrm{~mL}$ were preserved with $1 \mathrm{~mL}$ of $1 \%$ nitric acid and $20000 \mathrm{mg} \mathrm{L}^{-1}$ strontium chloride. All solute concentrations are expressed in $\mathrm{mg} \mathrm{L}^{-1}$, with a precision of $\pm 5 \%$. Several different indices were used to relate solute composition and origin: total dissolved solids (TDS), non-sea-salt calcium (Ca*) (Lyons and others, 2003), non-sea-salt sulphate $\left(\mathrm{nssSO}_{4}\right)$ (Stenni and others, 2000), the sodium to chloride ratio $(\mathrm{Na}: \mathrm{Cl})$ which approximates $0.55 \mathrm{mg} \mathrm{L}^{-1}$ for marine-originated salts (Lyons and others, 2003), and the monovalent to bivalent base cation ratio $\left(\mathrm{Na}^{+}+\mathrm{K}^{+}\right) /\left(\mathrm{Ca}^{2+}+\mathrm{Mg}^{2+}\right)$ used by Souchez and Lemmens (1987) in temperate glaciers.

Sediment extracted from the ice samples was dried at $45^{\circ} \mathrm{C}$, weighed then sieved at $0.5 \phi$ increments. The amount of sediment smaller than $4 \phi$ was measured by pipette analysis (Lewis, 1984). Debris concentrations were calculated using the method of Holdsworth (1974) assuming densities of $2650 \mathrm{~kg} \mathrm{~m}^{-3}$ for sediment and $900 \mathrm{~kg} \mathrm{~m}^{-3}$ for ice.

\section{RESULTS}

\section{Isotope data}

The isotopic composition of the basal ice shows that there is high variability in the $\delta^{18} \mathrm{O}$ for the stratified facies, ranging from $-30 \%$ to $-34 \%$ (Fig. $3 \mathrm{~d}$ ). The englacial facies is similar to the stratified facies, but is less variable $\left(\delta^{18} \mathrm{O}\right.$ ranges from $-34 \%$ to $-32 \%$ ). By comparison, the amber facies tend to be tightly clustered between $\delta^{18} \mathrm{O}$ of $-37 \%$ and $-35 \%$, with only a few outliers around $\delta^{18} \mathrm{O}$ of $-34 \%$ (Fig. $3 \mathrm{~d}$ ). There is negative shift in both $\delta \mathrm{D}$ and $\delta^{18} \mathrm{O}$ between the stratified and amber facies $\left(\delta^{18} \mathrm{O}\right.$ of $-33 \%$ and $-36 \%$ respectively),

Table 1. Average strain rates $\left(s^{-1} d\right)$ in the tunnel

\begin{tabular}{lllll}
\hline & $\dot{\varepsilon}_{1}$ & $\dot{\varepsilon}_{2}$ & $\dot{\varepsilon}_{3}{ }^{*}$ & $\dot{\gamma}^{\dagger}$ \\
\hline Amber & 0.2440 & -0.3008 & 0.0568 & 0.2724 \\
Stratified & 0.0628 & -0.0679 & 0.0051 & 0.0654 \\
\hline
\end{tabular}

\footnotetext{
${ }^{*} \dot{\varepsilon}_{1}+\dot{\varepsilon}_{2}+\dot{\varepsilon}_{3}=0$.
}

${ }^{\dagger} \dot{\gamma}=\left(\dot{\varepsilon}_{1}-\dot{\varepsilon}_{2}\right) / 2$. 


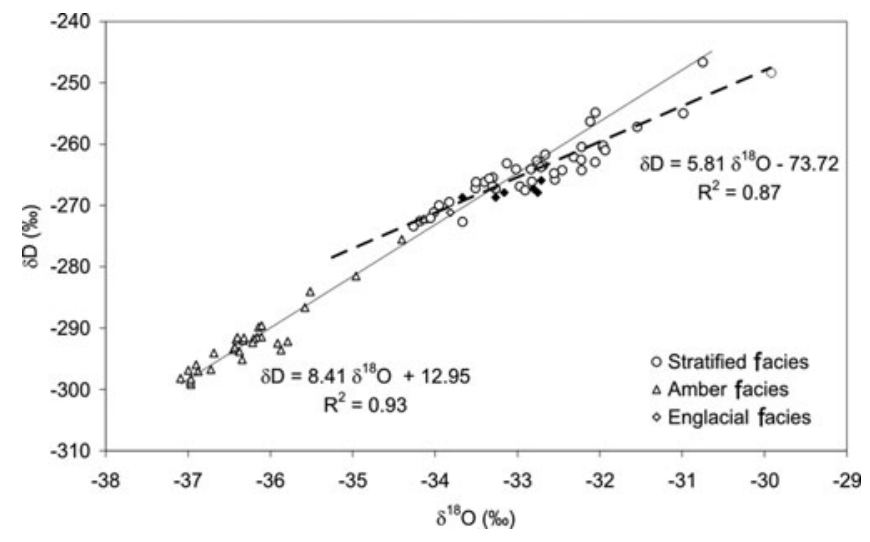

Fig. 4. Co-isotopic composition of the basal zone of Rhone Glacier. The stratified facies plot on a slope of 5.8, and the amber facies plot on a slope of 8.4 .

which occurs at the boundary between the two facies (Fig. $3 \mathrm{~d}$ and e). On this basis, there is clearly a difference in the isotopic composition of the amber ice, and there is no difference between the stratified and englacial ice.

Under normal conditions, $\delta \mathrm{D}$ and $\delta^{18} \mathrm{O}$ plots on a slope $\sim 8$, known as a meteoric waterline. This meteoric waterline is statistically derived from water measurements globally, with some local variation depending on altitude, elevation and distance from the ocean. However, when water is progressively frozen, there is a systematic change in the relationship between $\delta \mathrm{D}$ and $\delta^{18} \mathrm{O}$ (Jouzel and Souchez, 1982; Souchez and Jouzel, 1984). The result is that the isotopic composition of ice formed from liquid water plots on a slope $\sim 5$, known as a freezing slope (Souchez and Jouzel, 1984). For a closed system, the slope is dependent on the initial isotopic signature of the parent material as described by:

$$
S=\frac{(\alpha-1)}{(\beta-1)} \frac{\left(1000+\delta_{0} \mathrm{D}\right)}{\left(1000+\delta_{0}{ }^{18} \mathrm{O}\right)},
$$

where $S$ is the slope of the co-isotopic plot, $\alpha$ is the fractionation coefficient for ${ }^{2} \mathrm{H} /{ }^{1} \mathrm{H}$ (1.0212), $\beta$ is the fractionation coefficient for ${ }^{18} \mathrm{O} /{ }^{16} \mathrm{O}(1.00291)$ and $\delta_{0}$ is the isotopic composition of the initial parent water (Jouzel and Souchez, 1982).

Regression of all the basal ice data yielded the equation $\delta \mathrm{D}=(7.80 \pm 0.02) \delta^{18} \mathrm{O}-9.28\left(r^{2}=0.97\right)$, which is less than the local meteoric waterline (LMWL) which has a slope of 8.1 calculated from nearby Suess Glacier (Lorrain and others, 1999). The slope, 7.8, lies between the LMWL and a theoretical freezing slope, and is an artefact of the different isotopic compositions between the ice facies. When analysed separately, the isotopic values of the stratified facies show a linear relationship $\delta \mathrm{D}=(5.8 \pm 0.1) \delta^{18} \mathrm{O}-73.7\left(r^{2}=0.87\right)($ Fig. 4). Using the isotopic values of englacial facies $(n=7)$ as parent waters, the freezing slopes range between 5.45 and 5.53 for a closed system, and represent a freezing envelope (Hubbard and Sharp, 1995) for the ice facies. This freezing envelope is consistent with the closed-system freezing slope calculated for Suess Glacier of 5.5 (Lorrain and others, 1999). Thus, the slope of 5.8 with a $95 \%$ confidence interval of \pm 0.1 for the stratified facies is statistically different from the theoretical freezing envelope, which is inconsistent with ice formed by the freezing of water alone. By comparison, the co-isotopic

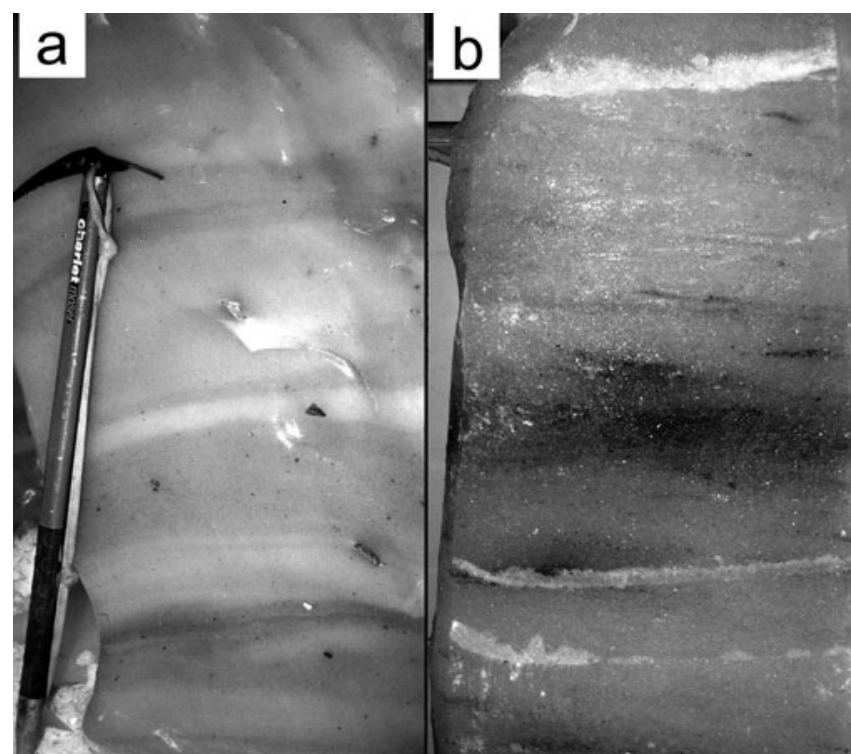

Fig. 5. (a) The amber facies is characterized by its evenly dispersed fine-grained sediment, opaque appearance and yellow colour. In Rhone Glacier the amber facies has distinctive banding, and suspended angular pebble-sized clasts. (b) The stratified facies contains alternating bands of clear, bubbly ice and debris-enriched layers.

slope for the amber facies shows a linear relationship $\delta \mathrm{D}=(8.4 \pm 0.2) \delta^{18} \mathrm{O}+12.9\left(r^{2}=0.93\right)$ (Fig. 4). The slope, 8.4 , has a $95 \%$ confidence interval of \pm 0.2 , which is statistically indistinguishable from the slope of the LMWL of 8.1 (Lorrain and others, 1999).

\section{Debris concentrations and particle size data}

Debris concentrations from the basal ice vary from $0 \%$ to $4 \%$ by volume and vary considerably across the different facies (Fig. 3b). The englacial facies contain little to no debris, and most samples lacked detectable sediment. The amber facies is characterized by alternating dark and light bands with randomly distributed angular pebbles up to $30 \mathrm{~mm}$ in diameter (Fig. 5a). The average sediment concentration of the amber facies is $0.8 \%$ by volume, with a range of $0.1-2.9 \%$. The stratified facies is characterized by alternating clean and debris-bearing layers (Fig. 5b) and has an average sediment concentration of $0.4 \%$ by volume, with a range of $0-3.8 \%$ (Table 2 ). The peaks in sediment concentration in the stratified facies generally reflect concentrations of predominantly sand-sized particles. In the amber facies, however, high concentrations of sediment are associated with large pebbles.

The particle size data show little difference in debris content between the stratified and amber facies. Both are characterized by polymodal distributions, with a dominant sand-sized mode (Fig. 6a). Both facies have relatively little silt $(2-3 \%)$, and the bulk of the sediment is pebbly sand ( $85 \%$ sand). The average particle size of debris in the Rhone Glacier amber facies $(0.4 \mathrm{~mm}$ or $1.5 \phi)$ is similar to that reported by Holdsworth (1974) for Meserve Glacier, which ranged between 0.2 and $0.7 \mathrm{~mm}$. Comparison of the cumulative frequency data for Meserve Glacier (Holdsworth, 1974) and this study (Fig. 6b) shows that particle size distribution is similar between the two study sites, with the 50th percentile between 0.2 and $0.4 \mathrm{~mm}$ for all three samples. The Meserve Glacier amber ice, however, has $\sim 10 \%$ silt, $65 \%$ sand and $25 \%$ gravel. 
Table 2. Average solute concentration in $\mathrm{mg} \mathrm{L}^{-1}$ of ice facies identified in Rhone Glacier basal ice. The $\mathrm{pH}$ value is a median, and debris concentration is expressed as a volume percentage

\begin{tabular}{|c|c|c|c|c|c|c|c|c|c|c|c|c|c|c|c|c|c|c|}
\hline Facies & $\mathrm{Na}^{+}$ & $\mathrm{Mg}^{2+}$ & $\mathrm{K}^{+}$ & $\mathrm{Ca}^{2+}$ & $\mathrm{NH}_{4}^{+}$ & $\mathrm{Cl}^{-}$ & $\mathrm{F}^{-}$ & $\mathrm{SO}_{4}{ }^{2-}$ & $\mathrm{NO}_{3}^{-}$ & $\mathrm{PO}_{4}{ }^{3-}$ & $\mathrm{Na} / \mathrm{Cl}$ & $\begin{array}{c}(\mathrm{Na}+\mathrm{K}) / \\
(\mathrm{Ca}+\mathrm{Mg})\end{array}$ & $\mathrm{nssSO}_{4}$ & $\mathrm{Ca}^{*}$ & $\begin{array}{l}\text { Debris } \\
\text { conc. }\end{array}$ & TDS & $\mathrm{pH}$ & $n$ \\
\hline ratified & 2.3 & 0.5 & 1.1 & 1.5 & 0.2 & 4.3 & 0.1 & 2.3 & 0.4 & 0.0 & 0.5 & 2.0 & 1.8 & 1.3 & 0.36 & 12.3 & 5.7 & 35 \\
\hline Amber & 6.3 & 1.2 & 1.5 & 3.0 & 0.8 & 11.4 & 0.1 & 5.6 & 0.6 & 0.1 & 0.6 & 1.9 & 4.1 & 2.8 & 0.73 & 30.7 & 6.1 & 9 \\
\hline Englacial & 1.5 & 0.4 & 1.0 & 0.8 & 0.1 & 3.7 & 0.2 & 1.6 & 0.2 & 0.0 & 0.4 & 2.1 & 1.2 & 0.7 & 0.00 & 9.4 & 6.1 & 7 \\
\hline
\end{tabular}

\section{Solute concentrations}

The peaks in TDS in the stratified and amber facies broadly correlate with peaks in debris concentration (Fig. 3c). Solute concentrations in the amber facies are significantly higher than in either the stratified or the englacial facies (Table 2). However, solute concentrations in the stratified and englacial facies are not statistically different because clean ice layers with low solute concentrations dominate both facies. Solute measurements from Rhone Glacier show that amber ice is significantly enriched compared to englacial ice, with TDS three times greater than that of the englacial facies (Fig. 3c). The dominant cation was sodium $\left(6.3 \mathrm{mg} \mathrm{L}^{-1}\right)$ followed by calcium ( $3.0 \mathrm{mg} \mathrm{L}^{-1}$ ) (Table 2$)$, and the concentrations are similar to those observed in Meserve Glacier by Holdsworth (1974). The average TDS for the englacial facies is $9.4 \mathrm{mg} \mathrm{L}^{-1}$, which is higher than has been reported for other glaciers. This points to the migration of solutes from the adjacent amber facies into the englacial facies, or mixing of adjacent ice types.

The average $\mathrm{nsSO}_{4}$ value is very high in the amber facies: $4.1 \mathrm{mg} \mathrm{L}^{-1}$ compared to 1.2 and $1.8 \mathrm{mg} \mathrm{L}^{-1}$ from the englacial and stratified facies respectively (Table 2). Likewise, the $\mathrm{Ca}^{*}$ value for the amber facies (2.8) is significantly larger than corresponding values for englacial (0.7) and stratified facies (1.3) (Table 2).

\section{Strain rates and ice velocity}

The velocity profile changes shape abruptly at the boundary between the stratified and amber facies (Figs 7a and 8a). The gradients of these two sections of the profile suggest that strain rates in the amber facies are higher than in the stratified facies. This is confirmed by the strain-rate data, which show that maximum principal strain rate $\left(\dot{\varepsilon}_{1}\right)$ and shear strain rate $(\gamma)$ in the amber facies are more than double those measured in the stratified facies (Figs $7 \mathrm{~b}$ and $8 \mathrm{~b}$ ). Figure $7 \mathrm{~b}$ also shows that the third principal strain rate $\left(\dot{\varepsilon}_{3}\right)$, which is oriented in the horizontal plane, is near zero in the amber facies, peaks at $2400 \mathrm{~mm}$ above the bed, then decreases at $3300 \mathrm{~mm}$ above the bed. This suggests that the central part of the tunnel wall has bulged slightly into the excavated space. Although there is evidence of wall bulging, the magnitude is small compared to the maximum strain rate and the shear strain rate (Fig. $7 b$; Table 1), which suggests that wall deformation has a negligible effect on the measurements. The velocity profile and strain-rate data show that the amber facies accommodates much greater strain than the stratified facies. Other deformation structures observed in the tunnel include air-filled cavities at the upstream and downstream ends of boulders in the ice (Fig. 8c) and a recumbent fold in the stratified facies. The roofs of the cavities were characterized by the presence of a

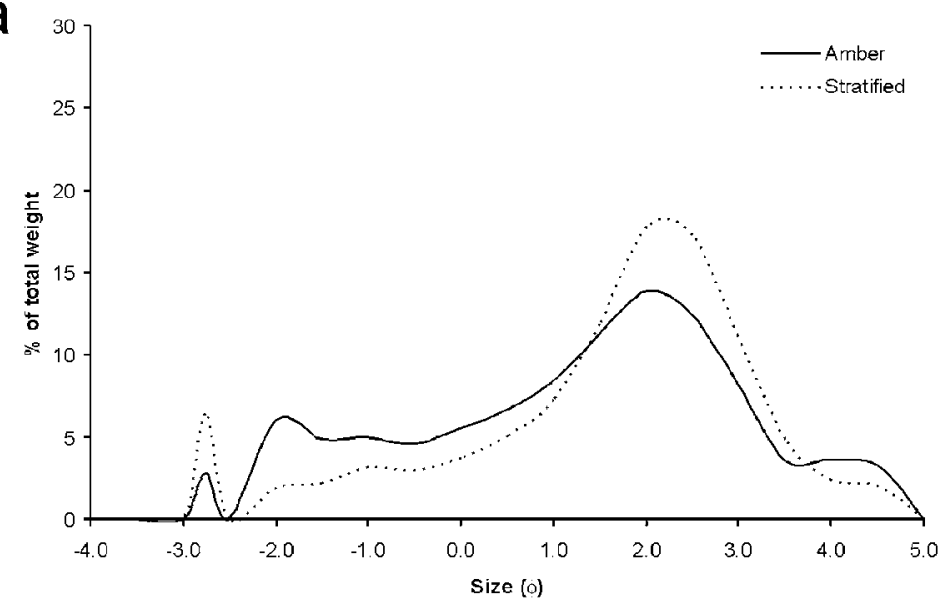

b

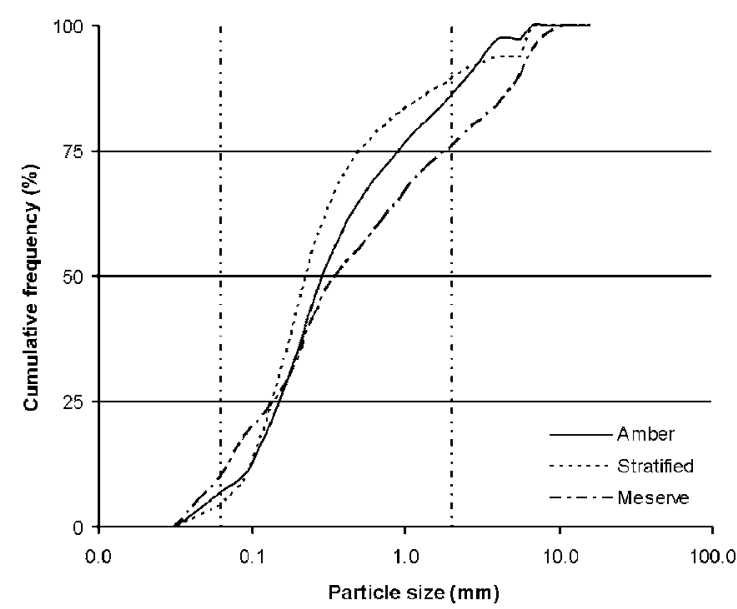

Fig. 6. (a) Particle size distribution for debris suspended in the stratified and amber ice facies in Rhone Glacier. Distribution is polymodal, with a dominant sand mode around $2 \phi$. (b) Cumulative frequency of particle size of debris suspended in Rhone Glacier. Solid curve is amber ice from Rhone Glacier, dotted curve is stratified ice from Rhone Glacier, and dash-dot curve is amber ice from Meserve Glacier (data from sample 54/0-10 from Holdsworth, 1974). 

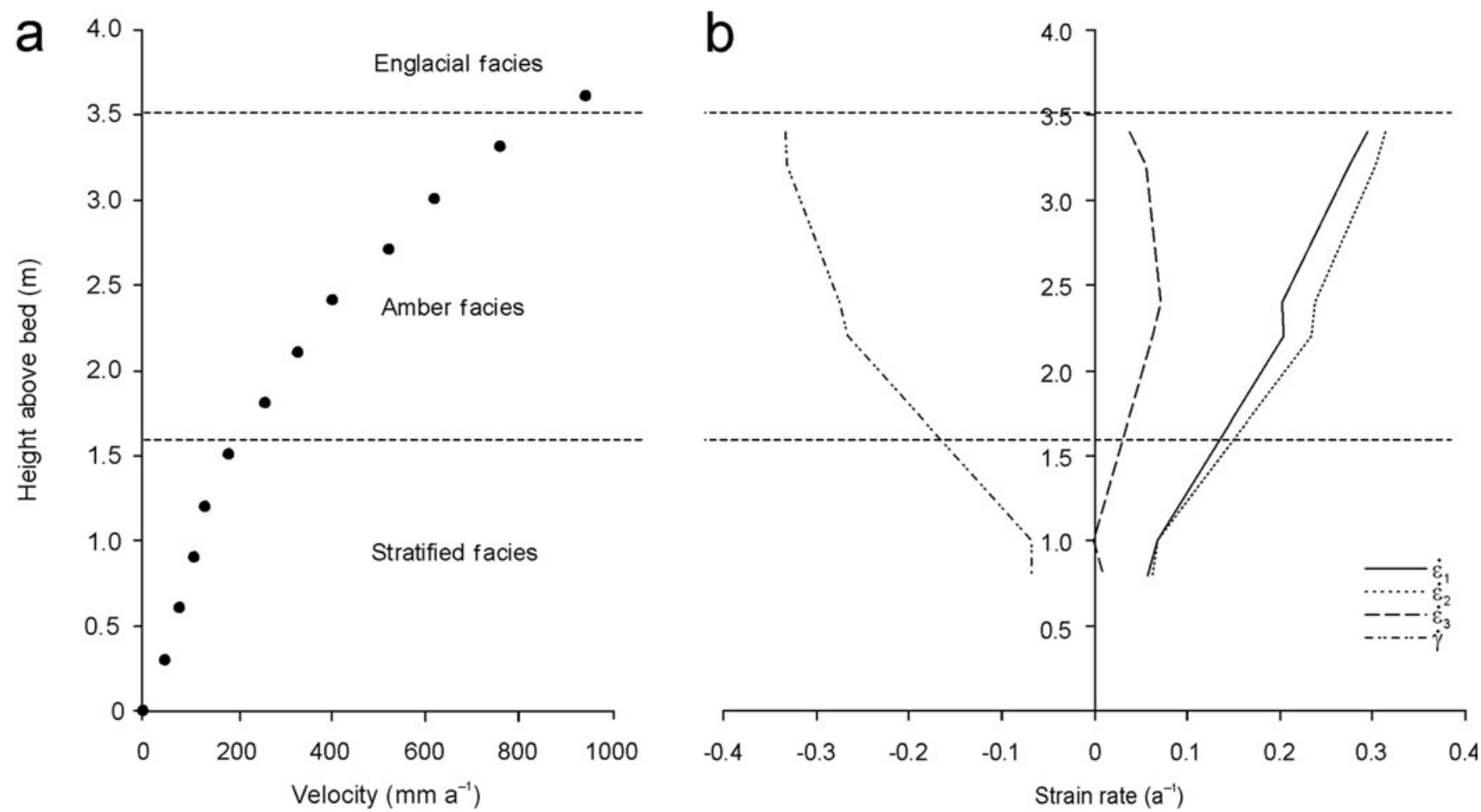

Fig. 7. (a) Velocity profile measured in the Rhone Glacier tunnel. (b) Plot of all principal strain rates exposed in tunnel of Rhone Glacier.

slickensides, which have been produced as the ice has become imprinted with small-scale roughness elements on the surfaces of the boulders.

\section{DISCUSSION}

The two basal ice facies have distinctive compositional signatures and experience different strain rates. Isotopic data from the amber facies suggest a meteoric origin. In contrast, data from the stratified facies show that liquid water played a significant role in its development.

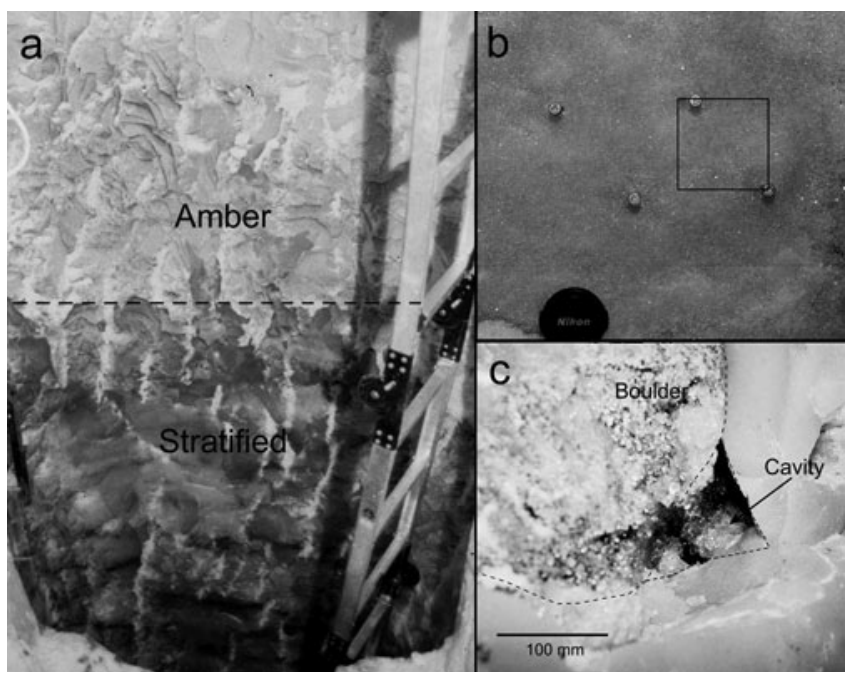

Fig. 8. (a) Photograph showing the contact between the stratified and amber facies in Rhone Glacier. (b) Photograph of the strain array 2 years after emplacement. Inset box outlines the original strain array configuration. (c) Air-filled cavity adjacent to a boulder in the basal ice.

\section{Origin of the amber facies}

Co-isotopic analysis of the amber facies demonstrates that the slope of the regression line (8.4) is statistically indistinguishable from the LMWL (8.1) at the 95\% confidence interval. This observation suggests that no liquid water was present when the amber facies formed. However, the amber facies is isotopically depleted compared to meteoric ice on average by $3 \% \delta^{18} \mathrm{O}$ and $25 \%$ oD. Such a pattern may be explained if the amber facies formed from meteoric processes when temperatures were cooler.

Other studies of snow and ice composition in an ice core extracted from Newall Glacier, $12 \mathrm{~km}$ east of Rhone Glacier, showed considerable variations in $\delta^{18} \mathrm{O}$ isotopic composition (Mayewski and others, 1995; P. Mayewski and S. Whitlow, http://nsidc.org/data/nsidc-0088.html). In particular, they show changes in $\delta^{18} \mathrm{O}$ values over the 50 years to 1987 (between $-28 \%$ and $-38 \%$ in $\delta^{18} \mathrm{O}$ between 1942 and 1985 , and with a minimum of $-42 \%$ occurring near the surface of the core). In palaeoclimatic terms, the more negative isotopic values represent periods of cooler atmospheric temperatures. Thus, an interpretation of the more negative isotopic values observed in the amber facies of Rhone Glacier could be that it is a relict from a cooler period. At Taylor Dome, $120 \mathrm{~km}$ to the west, Grootes and others (2001) showed that during the last glaciation, ice was isotopically lighter than Holocene ice by about 3\%, which is identical to the difference between the amber and meteoric ice in Rhone Glacier.

Although the isotopic data show that the amber facies plots on a meteoric slope, its hue, quantity of dissolved solids and suspended particles show that the physical characteristics of this ice layer have changed substantially since accumulation. The amber hue is commonly attributed to the presence of suspended fine-grained particles. However, analysis of particle size distributions of the amber 
Table 3. Comparison of characteristics of the amber ice from Meserve, Suess and Rhone glaciers

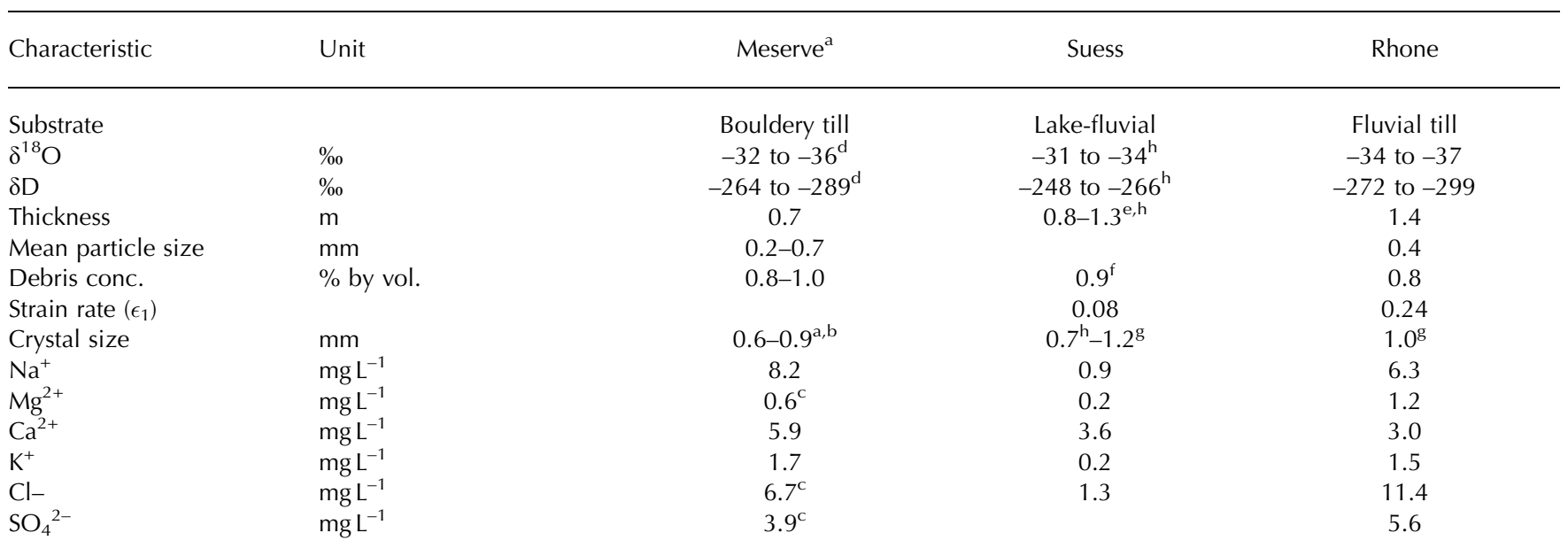

Data sources: ${ }^{a}$ Holdsworth (1974); ${ }^{\mathrm{b}}$ Anderton (1974); ${ }^{\mathrm{c} C u f f e y}$ and others (2000a); ${ }^{\mathrm{d} C u f f e y ~ a n d ~ o t h e r s ~(2000 b) ; ~}{ }^{\mathrm{e}}$ Lorrain and others (1999); ${ }^{\mathrm{f}}$ Fitzsimons and

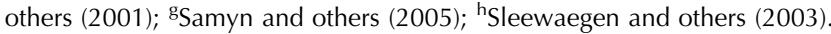

facies shows that silt accounts for only $2-3 \%$ of all suspended debris. The stratified facies also comprises $2 \%$ silt, but does not have the distinctive yellow hue of the amber ice. It is likely that the hue of the amber ice results from the even dispersal of particles throughout the ice, rather than the clumping and layering of sediment that occurs in the stratified facies. In addition, the presence of distinct bands within amber ice in Rhone Glacier distinguishes this facies from the apparently structureless amber facies in Suess Glacier. The appearance of banding may, however, be an artefact of sampling near the glacier terminus. Similar banding in amber ice was observed near the cliff face of Meserve Glacier (personal communication from K. Cuffey, 2008).

The sources of the dissolved and solid impurities remain uncertain. Holdsworth (1974) suggested that slow, solidstate diffusion entrained salts, but this does not explain the entrainment of rock fragments in amber ice that had abrasion gouges on quartz surfaces. In contrast, Cuffey and others $(2000 a, b)$ invoked the role of thin films of liquid water at interfaces that enabled the entrainment of impurities. The possibility that the rock particles were originally deposited by wind cannot be discounted, but the presence of angular pebbles up to $30 \mathrm{~mm}$ in diameter strongly suggests that the ice has been in contact with the glacier bed. Although our data do not shed any light on the entrainment process, the thickness and banding of the amber facies suggests there may have been considerable shortening and stacking of the sequence near the glacier margin. This suggestion is consistent with the presence of recumbent folds observed within the lower part of the amber facies.

High solute concentrations are characteristic of amber ice in the Dry Valleys (Holdsworth and Bull, 1970; Chinn, 1987; Fitzsimons and others, 2001) (Table 2). Its average TDS is nearly three times greater $\left(30.7 \mathrm{mg} \mathrm{L}^{-1}\right)$ than that of stratified facies. Both sulphate and calcium concentrations are greater in this facies and this may reflect prolonged contact with debris or the ground, particularly since mirabilite (sodium sulphate) is a common precipitate in arid areas like the McMurdo Dry Valleys (Keys and Williams, 1981). Sodium and chloride concentrations in Rhone Glacier amber facies are higher than in Meserve and Suess Glaciers (Table 3), and may be influenced by proximity to Lake Bonney. In temperate glaciers, if the solutes are derived from chemical or physical weathering of debris, enrichment of weatheringderived minerals like calcium and magnesium should result in a decrease in the $\left(\mathrm{Na}^{+}+\mathrm{K}^{+}\right) /\left(\mathrm{Ca}^{2+}+\mathrm{Mg}^{2+}\right)$ ratio. This ratio shows no significant difference between the three basal ice facies, although there is a statistically significant difference in the Ca* ratio for the amber facies. Keys and Williams (1981) found no significant aerosol source in the McMurdo Dry Valleys for magnesium, so its presence is from the weathering of dolerite and other magnesium-rich volcanic rocks. It follows that magnesium concentration may be a useful indicator of weathering in the McMurdo Dry Valleys. The relatively high concentrations of magnesium and nitrates in the amber facies compared with the englacial facies (Table 2) suggest that at least part of the solute load in the amber facies is derived from terrestrial chemical weathering.

The significance of solute concentrations from basal ice in cold glaciers is an area of some speculation due to sorption and desorption of salts at grain boundaries. The solutes may be sorbed onto particles in the amber facies or ions could be stored at grain boundaries within the ice matrix, then rapidly released upon melting. Desorption experiments have shown that the predominately rounded sandy grains do not provide a large storage site, and that such grains are not the primary storage sites for solutes (Hooker and others, 1999). Clay-sized particles, however, are electrically charged and have a much greater surface area for salts to sorb. If basal ice contains considerable amounts of clay-sized particles then the actual solute concentration of the ice will be difficult to determine. In the case of amber ice, where there are relatively coarse sand-sized grains, it is likely that the solutes will be between ice crystals or in liquid films (Dash and others, 2006). Regardless of where the solutes are stored, however, their presence probably results in an increase in liquid water within the ice (Wettlaufer, 1999). The presence of premelted liquid in amber ice probably determines the strength of the ice and its subsequent strain rate. The implications for ice dynamics are that a high-strain-rate material (amber ice) which is underlain by a low-strain-rate material (stratified ice) creates flow disturbance. These differences mean that 


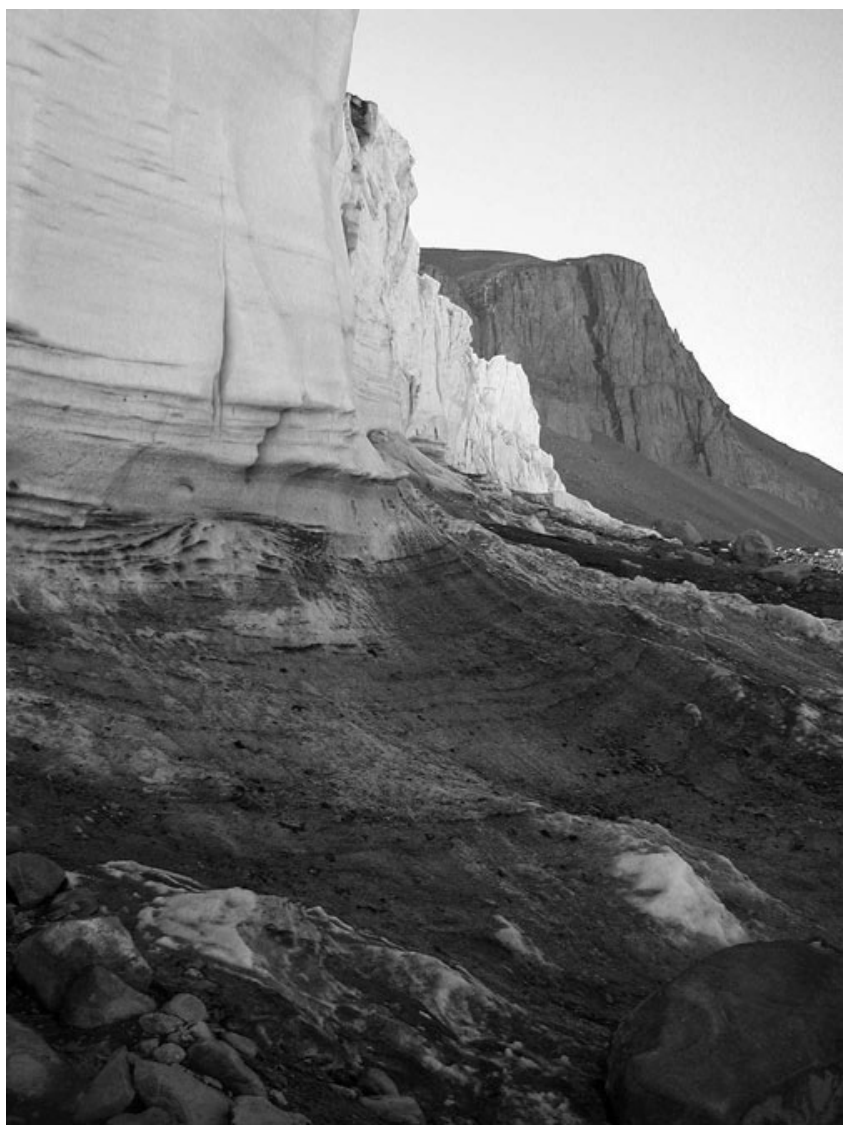

Fig. 9. Rhone Glacier apron photographed in the austral summer of 2001 showing the structure of apron ice, and distinct debris bands.

the stratified ice formed from the apron is effectively an obstruction to flow, causing overriding and folding. Thus, the banding observed in Rhone Glacier may reflect tectonic deformation and stacking of ice layers at the terminus.

\section{Origin of the stratified ice}

Isotopic composition of the basal facies shows that the stratified facies is isotopically heavier than the amber facies by about $3 \% \delta^{18} \mathrm{O}$ and $25 \% \delta \mathrm{D}$. Isotopic enrichment is commonly interpreted as evidence for fractionation during refreezing (e.g. Gow and Epstein, 1972; Hubbard and others, 2004). The interpretation that the stratified facies has experienced melt-freeze processes is also supported by the co-isotopic analysis because the stratified facies has a slope of $5.8 \pm 0.1$, which lies between the freezing slope and the meteoric waterline (Fig. 4).

Throughout its length, Rhone Glacier is thin and basal temperatures are likely to be well below the pressuremelting point. Freezing of subglacial water is an unlikely mechanism for the formation of ice because low basal ice temperatures preclude the presence of bulk meltwater. Like many other glaciers in the McMurdo Dry Valleys, Rhone Glacier's terminus is perched approximately $200 \mathrm{~m}$ above the valley floor and does not terminate in or near a proglacial lake, so en masse accretion of lake water is improbable. Consequently, interpretation of the stratified facies as the product of either regelation or net adfreezing is incompatible with the physical environment.

Holdsworth (1974) and Cuffey and others (2000b) concluded that ice at the base of Meserve Glacier (which is equivalent to the stratified facies in Rhone Glacier) was formed by assimilated calved ice and snow. Calved ice and debris that accumulates adjacent to the glacier forms an apron at the break in slope between the ice cliff and ground (Shaw, 1977). As the glacier advances over the apron, it becomes part of the basal zone where it is progressively stretched and sheared at the glacier sole, resulting in progressive thinning and folding. In this way, debris and salts that accumulated on the apron surface are entrained into the base of the advancing glacier (Shaw, 1977). Entrainment of the marginal apron ice and debris provides a good explanation of the physical characteristics of the stratified facies, because it explains the mixture of clean bubbly ice from calving, refrozen ice from cliff melt, debris from sublimated or melt-out till, or newly accumulated aeolian material. Such an origin is consistent with the co-isotopic analysis, which demon-strates that the $\delta \mathrm{D}-\delta^{18} \mathrm{O}$ slope is statistically different from the freezing slope and indicates that melt-refreezing processes dominate. Indeed a close examination of Figure 4 shows that many of the stratified facies samples plot on or near to the LMWL, yet others clearly plot away from this slope.

Observations made between December 1999 and January 2001 revealed that the front of the Rhone Glacier apron was dominated by outcrops of stratified basal ice that appear to be the external expression of the stratified facies encountered in the tunnel (Fig. 9). The form and structure of the apron contrasts strongly with those described by Shaw (1977) and Chinn (1991) which consist of highly attenuated foliated ice and debris ramps that extend steeply away from the ice cliff. We suggest that while the stratified ice may have been formed by apron overriding, at present ice is not accumulating on the apron and the formerly overridden apron is being transported to the glacier margin where it is melting (Fig. 9). This interpretation suggests that the terminus area is in a negative mass-balance state.

\section{Influence of amber ice on glacier behaviour}

The strain rates, together with the velocity profile measured through the amber ice, show that the highest strain rates occur in this ice facies and that much lower strain rates occur in the underlying stratified facies. Relatively high strain rates in the amber ice are consistent with direct shear tests on amber ice which demonstrate that the strength of this facies is significantly lower than that of the englacial ice and the stratified ice facies (Fitzsimons and others, 2001). Although we have not made any measurements of sliding at the stratified-ice/amber-ice boundary, the presence of slickensides on the roofs of cavities suggests that sliding occurs at this location (Fitzsimons and others, 1999). Taken together, the strain-rate contrasts between the stratified and amber ice and the inferred presence of sliding suggest that the amber ice is partly uncoupled from the underlying stratified ice and the glacier substrate.

The relatively high strain measured in the amber ice compared to both underlying and overlying ice facies has a direct impact on the shape of the velocity profile close to the glacier bed. That is, there is a very rapid change in strain and velocity within a thin band close to the glacier bed (Fig. 8). We suggest that the presence of a the thin soft band of amber ice supports a high strain rate close to the glacier bed, which results in a cliff at the ice margin. Formation of a cliff results in calving of ice blocks that accumulate at the foot of the cliff together with refrozen meltwater to form a distinctive apron around the glacier margin (Fitzsimons and others, 2008). When an ice 
margin advances, the apron becomes an impediment to ice flow, which produces a strongly compressive flow regime and overriding of the apron by the glacier. Such a situation results in thickening of the basal ice sequence as folds develop, and entrainment of the apron, which becomes the stratified basal ice that lies below the amber ice.

\section{Comparison of cold-based glacier basal facies}

Comparison of the basal ice sequences reveals that Rhone Glacier has close affinity to Meserve Glacier. Four basal ice facies were identified by Holdsworth (1974) at Meserve Glacier: englacial ice of meteoric origin; a wedge of clean ice situated close to the glacier margin and interpreted as assimilated drift snow, refrozen meltwater and calved ice cliff; yellow-greenish amber ice with diffused particles; and lenses of clean ice below the amber ice but above the effective bed that Holdsworth defined as the top of large basal boulders. By contrast, Cuffey and others (2000b) defined three basal ice facies which are the same as those described by Holdsworth but do not differentiate the layer of basal clear ice that Holdsworth found close to the glacier bed. Although the thickness of the comparable facies between Meserve and Rhone Glaciers differs, there is striking similarity in the basal ice facies. We interpret the stratified facies in Rhone Glacier as the equivalent of the combined clean assimilated snow, meltwater and cliff ice described by Holdsworth (1974) and Cuffey and others (2000b). The stratified facies at Rhone Glacier is thicker due to the terminal location in the tunnel from which the ice was sampled. Both Holdsworth (1974) and Cuffey and others (2000b) excavated tunnels at the glacier margin over $400 \mathrm{~m}$ upstream from the terminus, where aprons tend to be smaller.

It is likely that glaciers that reach the valley floor (e.g. Suess Glacier) have a fundamentally different basal ice sequence from those confined to valley sides. Glaciers that reach the valley floor flow over unconsolidated fluvial, lacustrine, aeolian and older glacial sediments (Humphreys and Fitzsimons, 1996) that are frequently interbedded with buried ice and/or segregated ice associated with permafrost processes. Glacier substrates that consist of unconsolidated fine-grained material are more erodible than hard rock or boulder veneer. Consequently the basal ice sequences of glaciers that reach the valley floor frequently entrain unconsolidated material from the glacier bed, so their basal ice sequences are characterized by structurally complex arrangements of ice and debris that are not present in glaciers confined to valley sides.

\section{CONCLUSIONS}

The facies architecture of Rhone Glacier comprises three types of ice. The bottom sequence is a stratified facies assembled from alternating layers of debris and englacial ice. Overlying the stratified facies at the terminus is an amber facies: a yellow-hued, massive ice with suspended pebbly-sand debris. The upper layer is clean, bubbly englacial ice. This architecture is similar to that observed in Meserve Glacier: a valley-wall confined glacier that is structurally simpler than Suess Glacier which reaches the valley floor.

This study has reached three principal conclusions:

1. The compositional signature of the amber facies is consistent with a meteoric origin which may have formed at a time when temperatures were considerably lower than at present. The solid and solute impurities indicate that the ice has experienced prolonged contact with the glacier substrate and that coarse particles within the ice have been entrained from the bed.

2. Isotopic data from the stratified facies plot on a coisotopic slope that demonstrates that liquid water played a significant role in ice formation. The distinctive isotopic signature shows that the ice was probably sourced from an overridden apron comprising meteoric-origin ice and refrozen meltwater.

3. The amber ice is weak, which results in high strain rates close to the glacier bed and a distinctive velocity profile characterized by a steep gradient adjacent to the bed. The presence of the amber ice at the glacier margin is conducive to the development of a cliff which in turn results in calving, the development of an apron, entrainment of the apron, formation of the stratified basal ice and thickening of the basal ice layer. Thus the amber ice is a fundamental control of glacier behaviour and margin morphology.

\section{ACKNOWLEDGEMENTS}

We thank the Marsden Fund and the University of Otago for financial support, and Antarctica New Zealand for logistical support. S. Mager acknowledges the support of a scholarship from Antarctica New Zealand. D. Samyn and R. Lorrain are indebted to the Belgian Antarctic programme (Science Policy Office) for financial support. We also thank K. Cuffey, P. Holland, E. Evans and an anonymous reviewer for substantial comments on the manuscript.

\section{REFERENCES}

Anderton, P.W. 1974. Ice fabrics and petrography, Meserve Glacier, Antarctica. J. Glaciol., 13(68), 285-306.

Chinn, T.J.H. 1987. Accelerated ablation at a glacier ice-cliff margin, Dry Valleys, Antarctica. Arct. Alp. Res., 19(1), 71-80.

Chinn, T.J.H. 1991. Polar glacier margin and debris features. Mem. Soc. Geol. Ital., 46, 25-44.

Cuffey, K.M., H. Conway, A. Gades, B. Hallet, C.F. Raymond and S. Whitlow. 2000a. Deformation properties of subfreezing glacier ice: role of crystal size, chemical impurities, and rock particles inferred from in situ measurements. J. Geophys. Res., 105(B12), 27,895-27,915.

Cuffey, K.M. and 8 others. 2000b. Entrainment at cold glacier beds. Geology, 28(4), 351-354.

Dash, J.G., A.W. Rempel and J.S. Wettlaufer. 2006. The physics of premelted ice and its geophysical consequences. Rev. Mod. Phys., 78(3), 695-741.

Donnelly, T., S. Waldron, A. Tait, J. Dougans and S. Bearhop. 2001. Hydrogen isotope analysis of natural abundance and deuteriumenriched waters by reduction over chromium on-line to a dynamic dual inlet isotope-ratio mass spectrometer. Rapid Commun. Mass Spectrom., 15(15), 1297-1303.

Doran, P.T. and 6 others. 2002. Valley floor climate observations from the McMurdo dry valleys, Antarctica, 1986-2000. J. Geophys. Res., 107(D24), 4772. (10.1029/2001JD002045.)

Farquhar, G.D., B.K. Henry and J.M. Styles. 1997. A rapid on-line technique for determination of oxygen isotope composition of nitrogen-containing organic matter and water. Rapid Commun. Mass Spectrom., 11(14), 1554-1560.

Fitzsimons, S.J., K.J. McManus and R.D. Lorrain. 1999. Structure and strength of basal ice and substrate of a dry-based glacier: 
evidence for substrate deformation at sub-freezing temperatures. Ann. Glaciol., 28, 236-240.

Fitzsimons, S.J., K.J. McManus, P. Sirota and R.D. Lorrain. 2001. Direct shear tests of materials from a cold glacier: implications for landform development. Quat. Int., 86(1), 129-137.

Fitzsimons, S., N. Webb, S. Mager, S. MacDonell, R. Lorrain and D. Samyn. 2008. Mechanisms of basal ice formation in polar glaciers: an evaluation of the apron entrainment model. J. Geophys. Res., 113(F2), F02010. (10.1029/2006JF000698.)

Gow, A.J. and S. Epstein. 1972. On the use of stable isotopes to trace the origins of ice in a floating ice tongue. J. Geophys. Res., 77(33), 6552-6557.

Grootes, P.M., E.J. Steig, M. Stuiver, E.D. Waddington, D.L. Morse and M.J. Nadeau. 2001. The Taylor Dome Antarctic $\delta^{18} \mathrm{O}$ record and globally synchronous changes in climate. Quat. Res., 56(3), 289-298.

Hambrey, M.J. and F. Müller. 1978. Structures and ice deformation in the White Glacier, Axel Heiberg Island, Northwest Territories, Canada. J. Glaciol., 20(82), 41-66.

Hambrey, M.J., A.G. Milnes and H. Siegenthaler. 1980. Dynamics and structure of Griesgletscher, Switzerland. J. Glaciol., 25(92), $215-228$.

Holdsworth, G. 1974. Meserve Glacier, Wright Valley, Antarctica: Part 1. Basal processes. Inst. Polar Stud. Rep. 37.

Holdsworth, G. and C. Bull. 1970. The flow law of cold ice: investigations on Meserve Glacier, Antarctica. IASH Publ. 86 (Symposium in Hanover, NH 1968 - Antarctic Glaciological Exploration (ISAGE)), 204-216.

Hooker, B.L., S.J. Fitzsimons and R.K. Morgan. 1999. Chemical characteristics and origin of clear basal ice facies in dry-based glaciers, South Victoria Land, Antarctica. Global Planet. Change, 22(1-4), 29-38.

Hubbard, B. and M. Sharp. 1995. Basal ice facies and their formation in the western Alps. Arct. Alp. Res., 27(4), 301-310.

Hubbard, B., N.F. Glasser, M.J. Hambrey and J. Etienne. 2004. A sedimentological and isotropic study of the origin of supraglacial debris bands: Kongsfjorden, Svalbard. J. Glaciol., 50(169), 157-170.

Humphreys, K.A. and S.J. Fitzsimons. 1996. Landform and sediment associations of dry-based glaciers in arid polar environments. Z. Geomorphol., 105, Suppl., 21-33.

Jouzel, J. and R.A. Souchez. 1982. Melting-refreezing at the glacier sole and the isotopic composition of the ice. J. Glaciol., 28(98), $35-42$.
Keys, J.R. and K. Williams. 1981. Origin of crystalline, cold desert salts in the McMurdo region, Antarctica. Geochim. Cosmochim. Acta, 45(12), 2299-2309.

Lewis, D.W. 1984. Practical sedimentology. New York, Hutchinson Ross.

Lorrain, R.D., S.J. Fitzsimons, M.J. Vandergoes and M. Stiévenard. 1999. Ice composition evidence for the formation of basal ice from lake water beneath a cold-based Antarctic glacier. Ann. Glaciol., 28, 277-281.

Lyons, W.B., K.A. Welch, A.G. Fountain, G.L. Dana, B.H. Vaughn and D.M. McKnight. 2003. Surface glaciochemistry of Taylor Valley, southern Victoria Land, Antarctica and its relationship to stream chemistry. Hydrol. Process., 17(1), 115-130.

Mayewski, P.A. and 11 others. 1995. An ice-core-based, Late Holocene history for the Transantarctic Mountains, Antarctica. In Elliot, D.H. and G.L. Blaisdell, eds. Contributions to Antarctic research IV. Washington, DC, American Geophysical Union, 33-45. (Antarctic Research Series 67. .

Ramsay, J.G. 1967. The folding and fracturing of rocks. New York, McGraw-Hill.

Samyn, D., A. Svensson, S.J. Fitzsimons and R.D. Lorrain. 2005. Ice crystal properties of amber ice and strain enhancement at the base of cold Antarctic glaciers. Ann. Glaciol., 40, 185-190.

Sharp, M., W. Lawson and R.S. Anderson. 1988. Tectonic processes in a surge-type glacier. J. Struct. Geol., 10(5), 499-515.

Shaw, J. 1977. Till body morphology and structure related to glacier flow. Boreas, 6(2), 189-201.

Sleewaegen, S., D. Samyn, S.J. Fitzsimons and R.D. Lorrain. 2003. Equifinality of basal ice facies from an Antarctic cold-based glacier. Ann. Glaciol., 37, 257-262.

Souchez, R.A. and J. Jouzel. 1984. On the isotopic composition in $\delta \mathrm{D}$ and $\delta^{18} \mathrm{O}$ of water and ice during freezing. J. Glaciol. 30(106), 369-372.

Souchez, R.A. and M.M. Lemmens. 1987. Solutes. In Gurnell, A.M and M.J. Clark, eds. Glacio-fluvial sediment transfer: an alpine perspective. Chichester, etc., John Wiley and Sons, 285-303.

Stenni, B. and 6 others. 2000. Snow accumulation rates in northern Victoria Land, Antarctica, by firn-core analysis. J. Glaciol., 46(155), 541-552.

Wettlaufer, J.S. 1999. Impurity effects in the premelting of ice. Phys. Rev. Lett., 82(12), 2516-2519.

Wilch, T.I., G.H. Denton, D.R. Lux and W.C. Mclntosh. 1993. Limited Pliocene glacier extent and surface uplift in middle Taylor Valley, Antarctica. Geogr. Ann., 75A(4), 331-351. 